\title{
Efficient Electrocatalytic Reduction of Furfural to Furfuryl Alcohol in a Microchannel Flow Reactor
}

\author{
Yiran Cao and Timothy Noël*৫
}

Department of Chemical Engineering and Chemistry, Sustainable Process Engineering, Micro Flow Chemistry \& Synthetic Methodology, Eindhoven University of Technology, De Rondom 70 (Helix, STO 1.37), 5612 AP Eindhoven, The Netherlands

ABSTRACT: Furfural is considered to be an essential biobased platform molecule. Recently, its electrocatalytic hydrogenation is regarded as a more environmentally friendly process compared to traditional catalytic hydrogenation. In this study, a new, continuous-flow approach enabling furfural electrocatalytic reduction was developed. In an undivided multichannel electrochemical flow reactor at ambient temperature and pressure in basic reaction conditions, the yield of furfuryl alcohol reached up to $90 \%$ in only $10 \mathrm{~min}$ residence time. Interestingly, the faradaic efficiency was $90 \%$, showing a good effectiveness of the consumed electrons in the generation of the targeted compound. Furthermore, the innovation lies in the direct electrolysis using the green solvent ethanol without the need for membrane separation or catalyst modification, which offers further proof for continuous and sustainable production in industry.

KEYWORDS: electrochemistry, flow chemistry, furfural, furfuryl alcohol, microreactor, flow electrochemistry

\section{INTRODUCTION}

Furfural is one of the most significant industrial biobased chemicals, which is obtained via dehydration of sugars, as obtained from a variety of agricultural products such as corncobs and wheat bran. ${ }^{1}$ It possesses extensive application prospects as a renewable, nonpetroleum-based platform molecule. ${ }^{1-6}$ Consequently, furfuryl alcohol is widely used as a monomer for the synthesis of furan resins. ${ }^{5}$ These polymers are used in thermoset polymer matrix composites, cements, adhesives, and coatings. It is also recognized as a valuable intermediate in the fields of agriculture, medicine, and dyes. ${ }^{6}$ Compared to conventional high-pressure hydrogenation processes, the electrolysis of furfural offers not only a promotion for agricultural waste utilization ${ }^{7}$ but also constitutes an energy-saving green process. ${ }^{8}$ Li's group recently reported an interesting electrocatalytic reduction of furfural to furfuryl alcohol in a divided cell using a cation exchange membrane. ${ }^{9}$ Recently, Koper et al. reviewed the state of the art for furfural electroreduction. ${ }^{10}$ The majority of the electrochemical reduction reactions were performed either with noble metal catalysts in batch electrochemical cells or required long residence times in flow-through electrochemical cells. ${ }^{11}$ Arguably, the remaining problems lie in the discontinuity of the batch process, the complexity of the utilized electrodes, and the limitation of the use of divided cells.
The electrocatalytic reduction is an intriguing example which enables the hydrogenation of molecules using adsorbed hydrogen at the electrode which originates from $\mathrm{H}^{+}$or $\mathrm{H}_{2} \mathrm{O}$ via the Volmer reaction (Scheme 1). ${ }^{12}$ Hence, the reaction can be

Scheme 1. Desired Electrocatalytic Hydrogenation of Furfural towards Furfuryl Alcohol versus Undesired Reactions

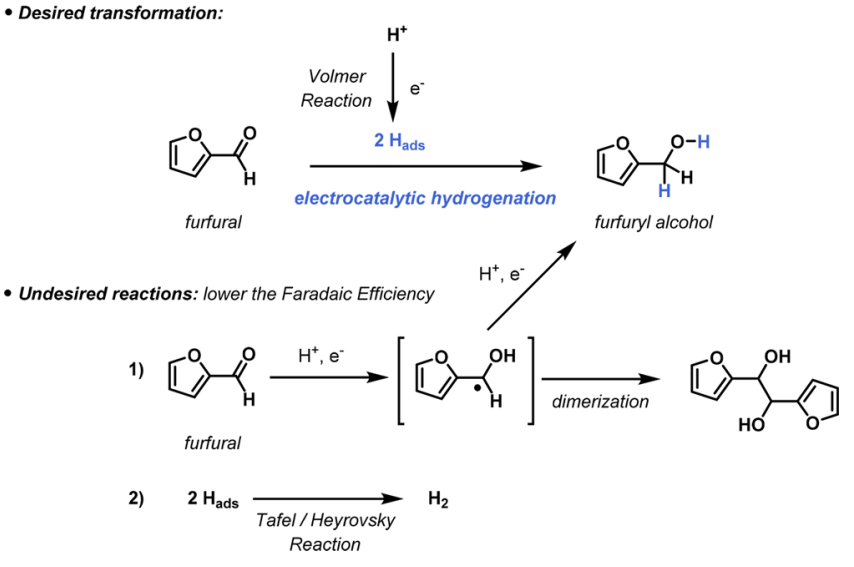

carried out at very mild reaction conditions (room temperature, atmospheric pressure, no $\mathrm{H}_{2}$ needed) and does not require expensive first or second row transition-metal-based catalysts. However, despite these apparent advantages in favor of electrocatalytic reductions, there are some challenges with regard to nonproductive competitive reactions (Scheme 1). One is the occurrence of hydrogen evolution where adsorbed hydrogen is consumed via the so-called Tafel and Heyrovsky reactions, ${ }^{13}$ which lowers the Faradaic efficiency of the transformation significantly. ${ }^{14}$ Another competitive transformation is the electroreduction of the carbonyl moiety to generate the respective radical. These radicals can consume another electron to generate the targeted furfuryl alcohol or can dimerize to generate undesired diols. Hence, efficient electrocatalytic reduction transformations require a careful balancing of all the different parameters (e.g., electrode material, reaction conditions) to favor the desired transformation over these unproductive pathways.

Herein, we report a continuous-flow direct electrolysis approach for electroreduction of furfural to address the above-

Received: December 7, 2018

Published: February 8, 2019 
mentioned issues using an electrochemical flow reactor developed in our group (Figure 1). ${ }^{15} \mathrm{Key}$ in the design of

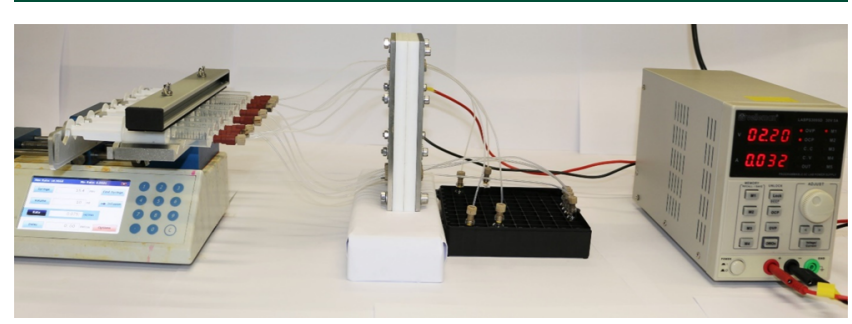

Figure 1. Continuous multichannel electrochemical flow reactor which allows for a rapid screening of key reaction conditions in parallel.

this electrochemical reactor is its flexible reactor volume, enabling two different operation modes, i.e. a serial (volume ranging from $88 \mu \mathrm{L} /$ channel up to $704 \mu \mathrm{L}$ ) or a parallel mode (numbering-up or parallel screening of reaction conditions) (Figure 2). ${ }^{96}$ In this reactor, we screened both basic and acidic
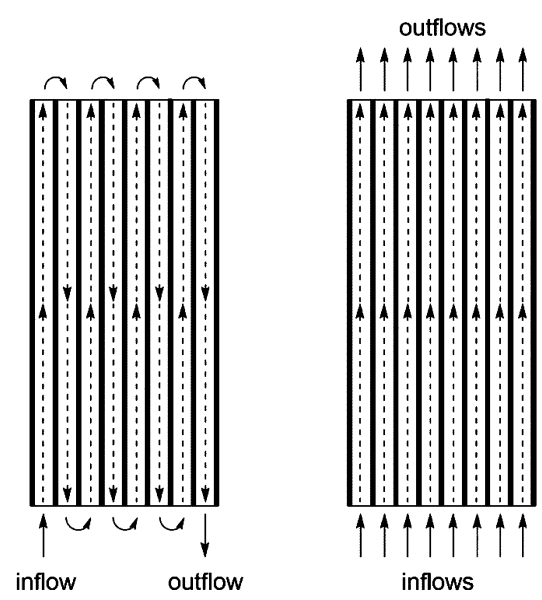

Figure 2. Serial mode (left) or parallel mode (right) operation of the electrochemical flow reactor.

reaction conditions, and our results indicate that a basic environment is optimal not only to obtain a high yield of the targeted furfuryl alcohol but also to obtain high Faradaic efficiencies.

\section{EXPERIMENTAL SECTION}

1. General Information. For the chemicals, furfural (99\%), furfuryl alcohol (98\%), 3-furancarboxaldehyde (97\%), furan-3-methanol (99\%), potassium hydroxide pellets (85\%), potassium ethoxide (95\%), sodium hydroxide pellets (98\%), and tetrabutylammonium bromide (99\%), were purchased from Sigma-Aldrich and used as received. Hydrochloric acid (37\%), ethanol (99.5\%), and acetonitrile (99\%) were bought from VWR. Sulfuric acid (98\%) was obtained from Merck. Ammoeng 110 Poly[oxy(methyl-1,2-ethanediyl)],a-[2(diethylmethylammonio)ethyl]-w-hydroxy-,chloride (1:1), 95\% was gained from Iolitec. One molar $\mathrm{HCl}$ and $0.5 \mathrm{M}$ $\mathrm{H}_{2} \mathrm{SO}_{4}$ solution were prepared by dilution with deionized water $(18.2 \mathrm{M} \Omega \cdot \mathrm{cm})$.

2. Flow Setup. For the flow setup, microsyringe pumps (Fusion 720, Chemyx) were used to infuse the liquid solutions. Before each set of experiments, stock solutions were prepared according to the different conditions as described herein. The liquids were taken up into disposable plastic syringes $(10 \mathrm{~mL}$, BD Discardit II) and mounted on the syringe pumps. Microfluidic connections between the electrochemical flow reactor and the syringes consisted of perfluoroalkoxy capillary tubing (ID $0.75 \mathrm{~mm}$ or $1.58 \mathrm{~mm}, \mathrm{PFA}$ ) and were attained from APT. Microfluidic connectors (LT-115X) and ferrules (P259X) were procured from IDEX. Electric power (0-30 V, 0$5 \mathrm{~A})$ was delivered by a LABPS3005D power supply. Electrode material (i.e., stainless steel $316 \mathrm{~L}$, copper $\mathrm{Cu}-\mathrm{DHP}$, and graphite) were bought at Salomon's Metalen B.V. The reactor body (reinforced iron plates and PTFE supporting containers) was manufactured by Equipment \& Prototype Center at Eindhoven University of Technology. It should be noted that the electrodes did not display any corrosion under the given reaction conditions. ${ }^{15,17}$

3. Voltammogram. Prior to each experiment, a voltammogram was acquired which determines the suitable electrochemical reaction conditions. ${ }^{18}$ As shown in Figure 3, a plateau appeared at $2.80-3.00 \mathrm{~V}$ in acidic electrolyte, while it situated

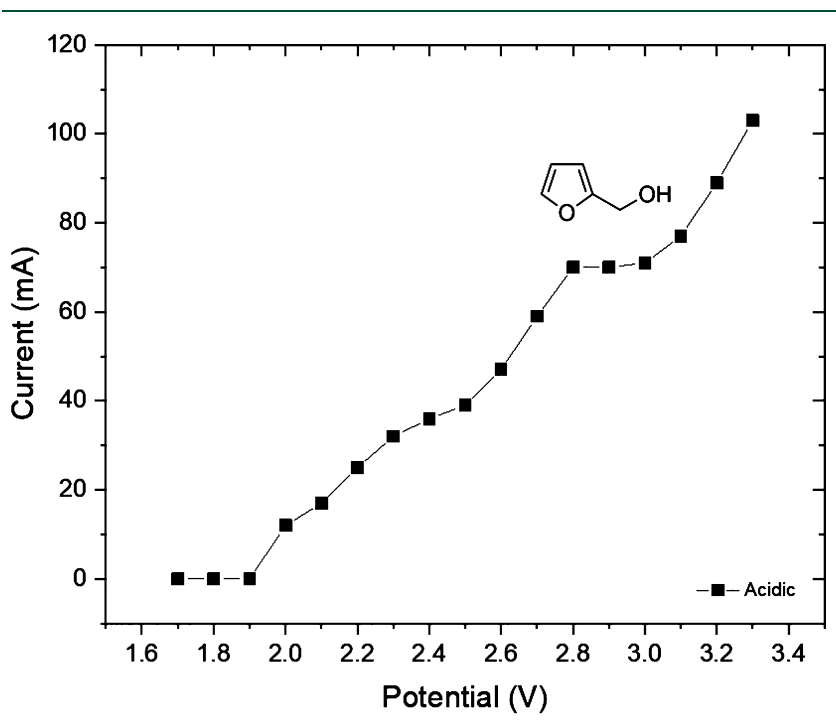

(A)

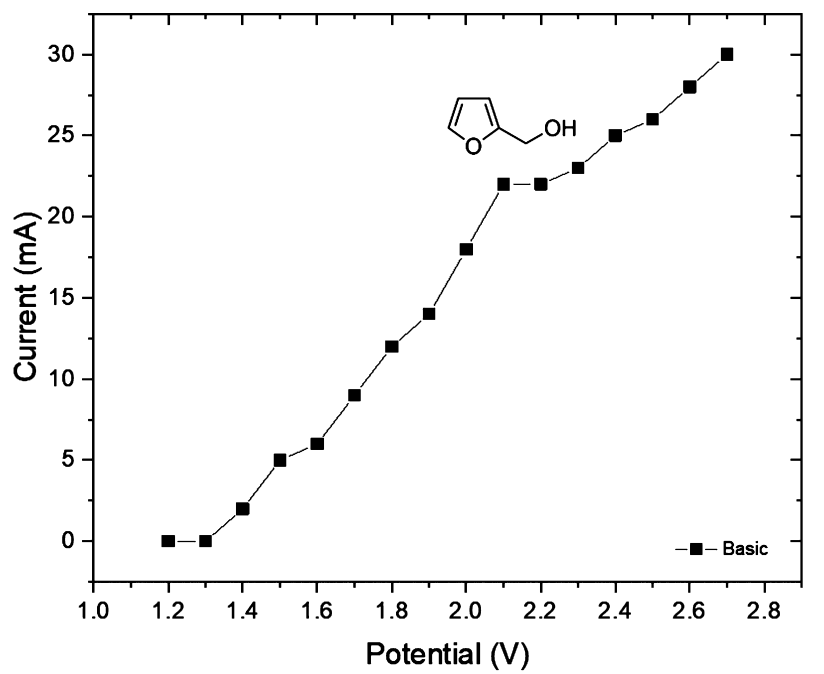

(B)

Figure 3. Voltammogram of furfural at a residence time of $10 \mathrm{~min}$ in acidic (A) or basic (B) reaction conditions. 
Table 1. Optimization for Furfuryl Alcohol Production in Acidic Environment ${ }^{a}$

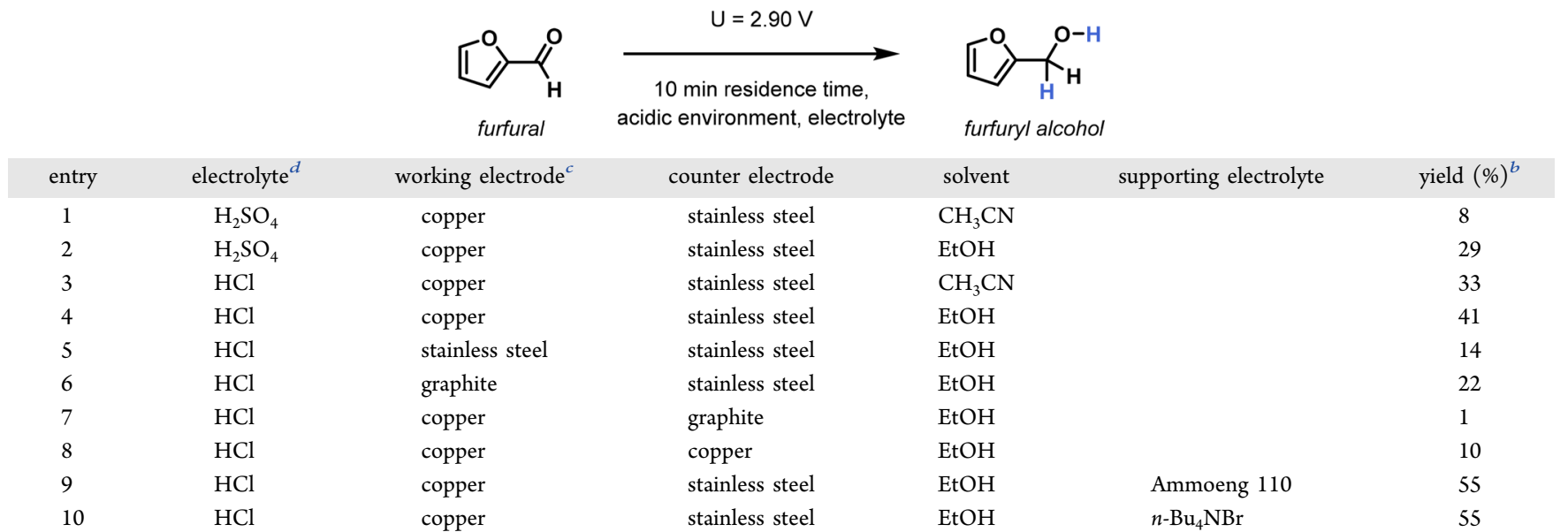

${ }^{a}$ Reaction conditions: $0.1 \mathrm{M}$ furfural, $0.1 \mathrm{M} \mathrm{H}^{+}, 0.05 \mathrm{M}$ supporting electrolyte, $10 \% \mathrm{H}_{2} \mathrm{O}$, flow rate $0.075 \mathrm{~mL} / \mathrm{min}$, residence time $10 \mathrm{~min} .{ }^{b} \mathrm{GC}$ yield using GC-FID with external standard calibration. ${ }^{c}$ The SAE international stainless steel type is $316 \mathrm{~L}$; the copper type is Cu-DHP. ${ }^{d}$ The molar concentration of $\mathrm{HCl}$ is $0.1 \mathrm{~mol} / \mathrm{L}$; the molar concentration of $\mathrm{H}_{2} \mathrm{SO}_{4}$ is $0.05 \mathrm{~mol} / \mathrm{L}$ in stock solution.

at $2.10-2.30 \mathrm{~V}$ in basic electrolyte. Therefore, 2.90 and $2.20 \mathrm{~V}$ were respectively chosen for subsequent optimization.

\section{RESULTS AND DISCUSSION}

We commenced our investigations toward the electroreduction of furfural in $0.5 \mathrm{M}$ sulfuric acid in combination with acetonitrile using a copper/stainless steel electrode pair (Table 1 , entry 1 ). However, only a yield of $8 \%$ was obtained for the targeted furfuryl alcohol. When switching to a more protic solvent such as ethanol, an increase in yield toward 29\% was witnessed (Table 1, entry 2). Interestingly, a further improvement was observed in the presence of hydrochloric acid (Table 1, entries 3 and 4). In contrast, changing the electrode material did not result into a further increase in yield (Table 1, entries 5-8), indicating that the combination of stainless steel/copper is optimal. Finally, we also checked the need for supporting electrolytes which are required to minimize the Ohmic drop in electrochemical processes. It is often claimed that microreactors do not require any supporting electrolytes due to small interelectrode gap. ${ }^{19,20}$ However, in our case, small amounts of electrolyte $(0.05 \mathrm{M})$, such as the ionic liquid Ammoeng 110 or $n-\mathrm{Bu}_{4} \mathrm{NBr}$, were beneficial to increase the overall yield.

Next, we turned our attention to basic reaction conditions using potassium ethoxide in ethanol. ${ }^{21,22}$ Interestingly, a substantial increase in the reaction yield was observed (Table 2 ). Varying the electrode material showed that the best results were obtained with a copper/graphite couple (Table 2, entry 3 ) yielding the targeted furfuryl alcohol in $90 \%$. Other bases, such as $\mathrm{NaOH}$ and $\mathrm{KOH}$, did not lead to any further improvement (Table 2, entries 6 and 7).

Given the importance of the use of acids or bases to effect the desired transformation, we next turned our attention to scan a wide variety of different concentrations (Table 3 ). For this specific experiment, our homemade electrochemical reactor design provided a clear and unique advantage as eight reaction conditions can be screened simultaneously in parallel in the eight different channels. Hence, we rapidly found that $0.10 \mathrm{M} \mathrm{HCl}$ and $0.05 \mathrm{M} \mathrm{C}_{2} \mathrm{H}_{5} \mathrm{OK}$ provided optimal results for electroreduction of furfural.

Having determined the relative importance of the reaction partners, we investigated the influence of the reaction time
Table 2. Optimization for Furfuryl Alcohol Production in Basic Environment ${ }^{a}$

\begin{tabular}{|c|c|c|c|c|}
\hline \multicolumn{2}{|r|}{ al } & $\begin{array}{l}10 \mathrm{~min} \text { residence } \\
\text { basic environment, el }\end{array}$ & $\begin{array}{l}\text { me, } \\
\text { ctrolyte }\end{array}$ & $\int_{\mathrm{H}}^{\mathrm{O}-\mathrm{H}}$ \\
\hline entry & electrolyte & working electrode ${ }^{c}$ & counter electrode & yield $(\%)^{b}$ \\
\hline 1 & $\mathrm{C}_{2} \mathrm{H}_{5} \mathrm{OK}$ & graphite & graphite & 25 \\
\hline 2 & $\mathrm{C}_{2} \mathrm{H}_{5} \mathrm{OK}$ & stainless steel & graphite & 46 \\
\hline 3 & $\mathrm{C}_{2} \mathrm{H}_{5} \mathrm{OK}$ & copper & graphite & 90 \\
\hline 4 & $\mathrm{C}_{2} \mathrm{H}_{5} \mathrm{OK}$ & copper & stainless steel & 43 \\
\hline 5 & $\mathrm{C}_{2} \mathrm{H}_{5} \mathrm{OK}$ & copper & copper & 10 \\
\hline 6 & $\mathrm{NaOH}$ & copper & graphite & 41 \\
\hline 7 & $\mathrm{KOH}$ & copper & graphite & 78 \\
\hline
\end{tabular}

${ }^{a}$ Reaction conditions: $0.1 \mathrm{M}$ furfural, $0.05 \mathrm{M}$ electrolyte, ethanol solvent, flow rate $0.075 \mathrm{~mL} / \mathrm{min}$, residence time $10 \mathrm{~min} .{ }^{b} \mathrm{GC}$-yield using GC-FID with external standard calibration. ${ }^{c}$ The SAE international stainless steel type is $316 \mathrm{~L}$; the copper type is $\mathrm{Cu}$ DHP. The counter electrode is graphite.

(Figure 3). Interestingly, in both acidic and basic media, the optimal residence time to reach full conversion is only $10 \mathrm{~min}$. We believe this very short residence time can be attributed to the large electrode surface-to-volume ratio and the short diffusion distances observed in the electrochemical microreactor. Indeed, when we carried out the reaction in a batch electrochemical cell, the yield dropped to $18 \%$ in acidic medium and $31 \%$ in basic conditions and requires $6 \mathrm{~h}$ of reaction time.

Next, we tested the influence of constant current or constant potential electrolysis conditions (Figure 4). Constant potential electrolysis offers a more stable and tunable selectivity, ${ }^{17}$ while constant current electrolysis provides a more controlled and constant reaction conversion. ${ }^{23}$ However, for the electroreduction of furfural, almost similar behavior was observed under these two operational regimes. This gives us a high level of flexibility: if higher selectivity is required, one can use the constant potential conditions, while galvanostatic conditions are preferred to establish an adequate chemical conversion in shorter time scales. However, it must be noted that even though we did use potentiostatic reaction conditions, the flow 
Table 3. Optimization of Electrolyte via 8-Channel Simultaneously Parallel Reactions

\begin{tabular}{|c|c|c|c|c|c|}
\hline channel $^{a}$ & electrolyte & $\begin{array}{l}\text { yield } \\
(\%)^{c}\end{array}$ & channel $^{b}$ & electrolyte & $\begin{array}{l}\text { yield } \\
(\%)^{c}\end{array}$ \\
\hline 1 & $0.05 \mathrm{M} \mathrm{HCl}$ & 22 & 1 & $\begin{array}{l}0.01 \mathrm{M} \\
\quad \mathrm{C}_{2} \mathrm{H}_{5} \mathrm{OK}\end{array}$ & 38 \\
\hline 2 & $0.07 \mathrm{M} \mathrm{HCl}$ & 35 & 2 & $\begin{array}{l}0.02 \mathrm{M} \\
\quad \mathrm{C}_{2} \mathrm{H}_{5} \mathrm{OK}\end{array}$ & 50 \\
\hline 3 & $0.09 \mathrm{M} \mathrm{HCl}$ & 46 & 3 & $\begin{array}{l}0.03 \mathrm{M} \\
\quad \mathrm{C}_{2} \mathrm{H}_{5} \mathrm{OK}\end{array}$ & 62 \\
\hline 4 & $0.10 \mathrm{M} \mathrm{HCl}$ & 55 & 4 & $\begin{array}{l}0.04 \mathrm{M} \\
\quad \mathrm{C}_{2} \mathrm{H}_{5} \mathrm{OK}\end{array}$ & 82 \\
\hline 5 & $0.11 \mathrm{M} \mathrm{HCl}$ & 53 & 5 & $\begin{array}{l}0.05 \mathrm{M} \\
\mathrm{C}_{2} \mathrm{H}_{5} \mathrm{OK}\end{array}$ & 90 \\
\hline 6 & $0.13 \mathrm{M} \mathrm{HCl}$ & 49 & 6 & $\begin{array}{l}0.06 \mathrm{M} \\
\mathrm{C}_{2} \mathrm{H}_{5} \mathrm{OK}\end{array}$ & 88 \\
\hline 7 & $0.15 \mathrm{M} \mathrm{HCl}$ & 46 & 7 & $\begin{array}{l}0.07 \mathrm{M} \\
\mathrm{C}_{2} \mathrm{H}_{5} \mathrm{OK}\end{array}$ & 86 \\
\hline 8 & $0.17 \mathrm{M} \mathrm{HCl}$ & 45 & 8 & $\begin{array}{l}0.08 \mathrm{M} \\
\mathrm{C}_{2} \mathrm{H}_{5} \mathrm{OK}\end{array}$ & 83 \\
\hline
\end{tabular}

${ }^{a}$ Reaction conditions: $0.1 \mathrm{M}$ furfural, $2.90 \mathrm{~V}, 10 \% \mathrm{H}_{2} \mathrm{O}$, ethanol solvent, flow rate $0.075 \mathrm{~mL} / \mathrm{min}$, residence time $10 \mathrm{~min} .{ }^{b}$ Reaction conditions: $0.1 \mathrm{M}$ furfural, $2.20 \mathrm{~V}$, ethanol solvent, flow rate 0.075 $\mathrm{mL} / \mathrm{min}$, residence time $10 \mathrm{~min}$. ${ }^{c} \mathrm{GC}$-yield using GC-FID with external standard calibration.
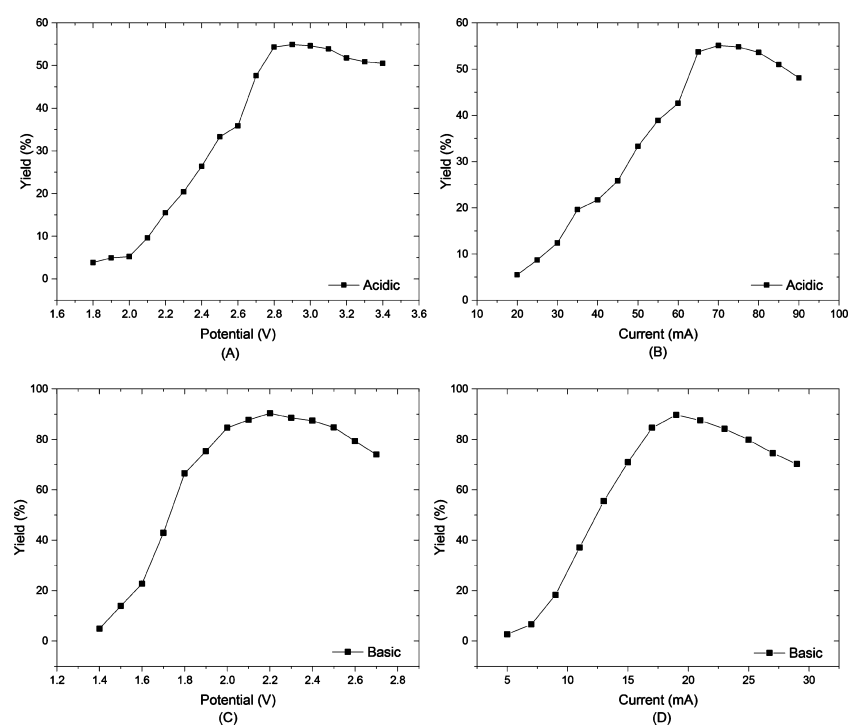

Figure 4. Constant-potential (A)(C) vs constant-current (B)(D) electrolysis.

processing enables us the keep the conversion time very short as described above $\left(t_{\mathrm{R}}=10 \mathrm{~min}\right.$, see Figure 5).

Having the optimal reaction conditions for the electroreduction of 2-furfural in hand (Table 4, entries 1 and 2), we investigated if the conditions were also applicable to 3-furfural (Table 4, entries 5 and 6). Interestingly, the same trend was observed for 3-furfural with the most optimal conversion and yield observed in basic media (Table 4, entry 6). In addition, for all the different conditions, we calculated the Faradaic efficiency: high Faradaic efficiencies were obtained for the basic reaction conditions (90-92\%), while in acidic media, very poor Faradaic efficiencies were observed (18-19\%). This can be attributed to the generation of higher amounts of hydrogen, as the hydrogen evolution reaction competes more efficiently with the electrocatalytic hydrogenation reaction in acidic reaction conditions. Interestingly, the corresponding batch conditions were not only considerably slower but also

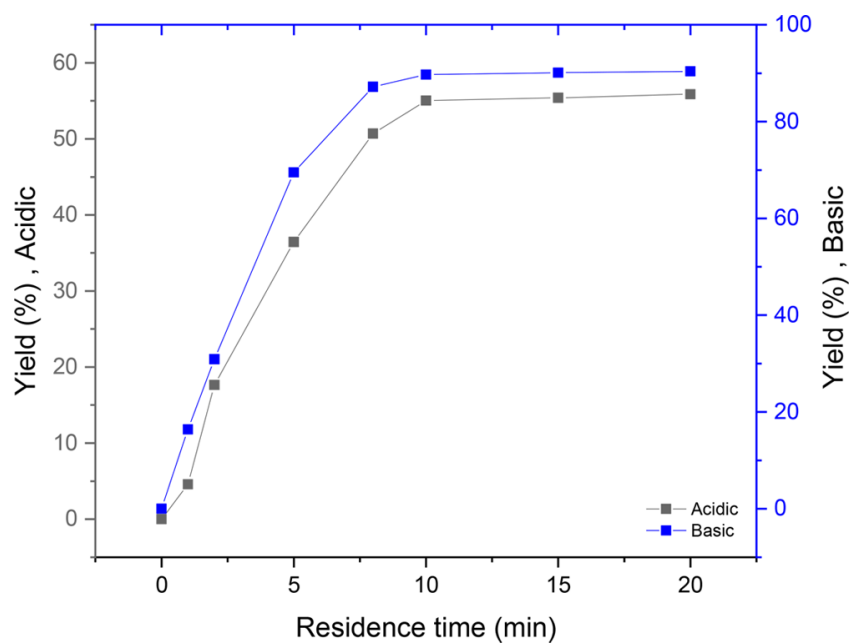

Figure 5. Influence of the residence time on the electroreduction of furfural to furfuryl alcohol in acidic and basic media.

Table 4. Scope for Furfural Electroreduction in Flow and Comparison with Batch Reaction Conditions

\begin{tabular}{|c|c|c|c|c|c|}
\hline entry & $\begin{array}{l}\text { reactor } \\
\text { type }\end{array}$ & substrate & electrolyte & $\begin{array}{l}\text { yield } \\
(\%)^{e}\end{array}$ & $\begin{array}{c}\text { faradaic } \\
\text { efficiency (\%) }\end{array}$ \\
\hline $1^{a}$ & flow & $\begin{array}{l}\text { furfural (2- } \\
\text { furaldehyde) }\end{array}$ & $\mathrm{HCl}$ & 55 & 19 \\
\hline $2^{b}$ & flow & $\begin{array}{l}\text { furfural (2- } \\
\quad \text { furaldehyde) }\end{array}$ & $\mathrm{C}_{2} \mathrm{H}_{5} \mathrm{OK}$ & 90 & 90 \\
\hline $3^{c}$ & batch & $\begin{array}{l}\text { furfural (2- } \\
\text { furaldehyde) }\end{array}$ & $\mathrm{HCl}$ & 18 & 12 \\
\hline $4^{d}$ & batch & $\begin{array}{l}\text { furfural (2- } \\
\text { furaldehyde) }\end{array}$ & $\mathrm{C}_{2} \mathrm{H}_{5} \mathrm{OK}$ & 31 & 60 \\
\hline $3^{a}$ & flow & $\begin{array}{l}\text { 3-furfural (3- } \\
\text { furaldehyde) }\end{array}$ & $\mathrm{HCl}$ & 40 & 18 \\
\hline $4^{b}$ & flow & $\begin{array}{l}\text { 3-furfural (3- } \\
\text { furaldehyde) }\end{array}$ & $\mathrm{C}_{2} \mathrm{H}_{5} \mathrm{OK}$ & 78 & 92 \\
\hline
\end{tabular}

${ }^{a}$ Reaction conditions: $0.1 \mathrm{M}$ furfural, $2.90 \mathrm{~V}, 0.1 \mathrm{M}$ electrolyte, $10 \%$ $\mathrm{H}_{2} \mathrm{O}$, ethanol solvent, flow rate $0.075 \mathrm{~mL} / \mathrm{min}$, residence time $10 \mathrm{~min}$. ${ }^{b}$ Reaction conditions: $0.1 \mathrm{M}$ furfural, $2.20 \mathrm{~V}, 0.05 \mathrm{M}$ electrolyte, ethanol solvent, flow rate $0.075 \mathrm{~mL} / \mathrm{min}$, residence time $10 \mathrm{~min}$. ${ }^{c}$ Reaction conditions: $0.1 \mathrm{M}$ furfural, $2.90 \mathrm{~V}, 0.1 \mathrm{M}$ electrolyte, $10 \%$ $\mathrm{H}_{2} \mathrm{O}$, ethanol solvent, residence time $300 \mathrm{~min} .{ }^{d}$ Reaction conditions: $0.1 \mathrm{M}$ furfural, $2.20 \mathrm{~V}, 0.05 \mathrm{M}$ electrolyte, ethanol solvent, residence time $300 \mathrm{~min}$. ${ }^{e} \mathrm{GC}$-yield using GC-FID with external standard calibration.

provided lower yields and Faradaic efficiencies (Table 4, entries 3 and 4). We surmise that the slower reaction times are due to mass transfer limitations and lower electrode surface-tovolume ratios and give more time for the undesired hydrogen formation reaction to occur.

Finally, we investigated the steady state production of 2furfuryl alcohol under these acidic and basic reaction conditions. We took reaction samples every $5 \mathrm{~min}$ and analyzed the obtained yield via GC-FID. The overall observed trend for both conditions showed a decline in yield over time. This decline can be attributed to erosion of the electrode efficiency. It was noteworthy, however, that the efficacy of the electrodes could be restored by incorporating an adequate cleaning and surface treatment step (Figure 6). This indicates that the reduced yield is caused by a deposition on the electrode surface which can be washed away effectively. ${ }^{24}$ To keep the reaction yield constant, we could place two reactors in parallel: one of them is in operation mode while the other one 


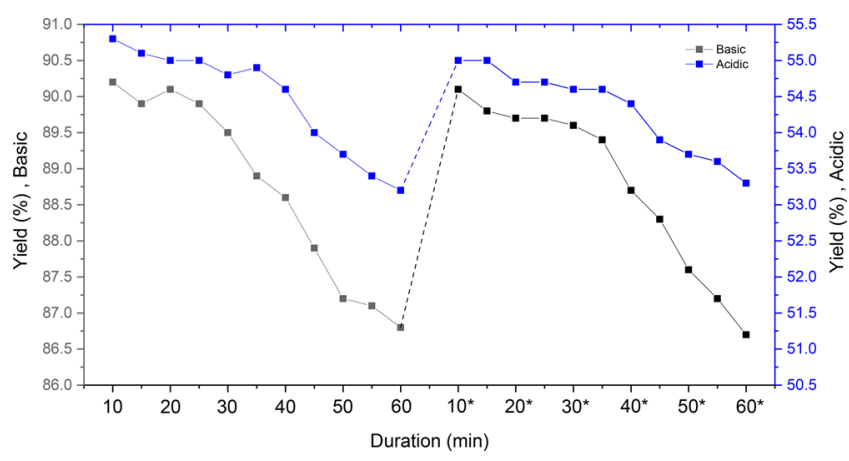

Figure 6. Two runs of stability test $(60 \mathrm{~min})$ for reactions (Table 4, entries 1 and 2) with 10 min residence time.

is in cleaning mode. When the yield drops, the modes can be switched and a "continuous" production of electrocatalytic reduction of furfural can be simulated.

\section{CONCLUSION}

In conclusion, we developed a continuous-flow protocol for the electrocatalytic reduction of furfural. Both acidic and basic reaction conditions were evaluated. We found that the basic reaction conditions delivered the highest yield for the targeted furfuryl alcohol and provided a high Faradaic efficiency. The reaction could be completed in only $10 \mathrm{~min}$ and required only a minimum amount of supporting electrolyte, highlighting the benefits of the microreactor environment. While an efficient process was established in flow, a reduced efficiency was observed due to pollution of the electrodes. However, we found that a cleaning step could alleviate this issue effectively.

\section{ASSOCIATED CONTENT}

\section{S Supporting Information}

The Supporting Information is available free of charge on the ACS Publications website at DOI: 10.1021/acs.oprd.8b00428.

(i) Design details of the electrochemical batch and flow reactor; (ii) details on the calculation of the Faradaic efficiency; (iii) GC results for the optimal reaction conditions; (iv) detailed procedure for the cleaning of our electrodes (PDF)

\section{AUTHOR INFORMATION}

\section{Corresponding Author}

*E-mail: t.noel@tue.nl.

\section{ORCID $\odot$}

Timothy Noël: 0000-0002-3107-6927

Notes

The authors declare no competing financial interest.

\section{ACKNOWLEDGMENTS}

The authors acknowledge support from the China Scholarship Council (CSC).

\section{REFERENCES}

(1) Mariscal, R.; Maireles-Torres, P.; Ojeda, M.; Sádaba, I.; López Granados, M. Furfural: A Renewable and Versatile Platform Molecule for the Synthesis of Chemicals and Fuels. Energy Environ. Sci. 2016, 9 (4), 1144-1189.

(2) LaForge, F. B. Furfural from Corncobs. Ind. Eng. Chem. 1923, 15 (5), 499-502.
(3) Riera, F. A.; Alvarez, R.; Coca, J. Production of Furfural by Acid Hydrolysis of Corncobs. J. Chem. Technol. Biotechnol. 1991, 50 (2), 149-155.

(4) Sánchez, C.; Serrano, L.; Andres, M. A.; Labidi, J. Furfural Production from Corn Cobs Autohydrolysis Liquors by Microwave Technology. Ind. Crops Prod. 2013, 42 (1), 513-519.

(5) Gandini, A.; Belgacem, M. N. Furans in Polymer Chemistry. Prog. Polym. Sci. 1997, 22 (6), 1203-1379.

(6) Eseyin, E. A.; Steele, H. P. An Overview of the Applications of Furfural and Its Derivatives. Int. J. Adv. Chem. 2015, 3 (2), 42-47.

(7) Möhle, S.; Zirbes, M.; Rodrigo, E.; Gieshoff, T.; Wiebe, A.; Waldvogel, S. R. Modern Electrochemical Aspects for the Synthesis of Value-Added Organic Products. Angew. Chem., Int. Ed. 2018, 57 (21), 6018-6041.

(8) Chamoulaud, G.; Floner, D.; Moinet, C.; Lamy, C.; Belgsir, E. M. Biomass Conversion II: Simultaneous Electrosyntheses of Furoic Acid and Furfuryl Alcohol on Modified Graphite Felt Electrodes. Electrochim. Acta 2001, 46 (18), 2757-2760.

(9) Chadderdon, X. H.; Chadderdon, D. J.; Matthiesen, J. E.; Qiu, Y.; Carraher, J. M.; Tessonnier, J.-P.; Li, W. Mechanisms of Furfural Reduction on Metal Electrodes: Distinguishing Pathways for Selective Hydrogenation of Bioderived Oxygenates. J. Am. Chem. Soc. 2017, 139 (40), 14120-14128.

(10) Kwon, Y.; Schouten, K. J. P.; van der Waal, J. C.; de Jong, E.; Koper, M. T. M. Electrocatalytic Conversion of Furanic Compounds. ACS Catal. 2016, 6 (10), 6704-6717.

(11) Parpot, P.; Bettencourt, A. P.; Chamoulaud, G.; Kokoh, K. B.; Belgsir, E. M. Electrochemical Investigations of the OxidationReduction of Furfural in Aqueous Medium - Application to Electrosynthesis. Electrochim. Acta 2004, 49 (3), 397-403.

(12) Guena, T.; Pletcher, D. Electrosyntheses from Aromatic Aldehydes in a Flow Cell. Part I. The Reduction of Benzaldehyde. Acta Chem. Scand. 1998, 52, 23-31.

(13) de Chialvo, M. R. G.; Chialvo, A. C. Hydrogen Evolution Reaction: Analysis of the Volmer-Heyrovsky-Tafel Mechanism with a Generalized Adsorption Model. J. Electroanal. Chem. 1994, 372 (1), 209-223.

(14) Yuan, H.; He, Z. Platinum Group Metal-Free Catalysts for Hydrogen Evolution Reaction in Microbial Electrolysis Cells. Chem. Rec. 2017, 17 (7), 641-652.

(15) Laudadio, G.; de Smet, W.; Struik, L.; Cao, Y.; Noël, T. Design and Application of a Modular and Scalable Electrochemical Flow Microreactor. J. Flow Chem. 2018, 8 (3), 157-165.

(16) Pletcher, D.; Green, R. A.; Brown, R. C. D. Flow Electrolysis Cells for the Synthetic Organic Chemistry Laboratory. Chem. Rev. 2018, 118 (9), 4573-4591.

(17) Laudadio, G.; Straathof, N. J. W.; Lanting, M. D.; Knoops, B.; Hessel, V.; Noël, T. An Environmentally Benign and Selective Electrochemical Oxidation of Sulfides and Thiols in a ContinuousFlow Microreactor. Green Chem. 2017, 19, 4061-4066.

(18) Nicholson, R. S.; Shain, I. Theory of Stationary Electrode Polarography. Single Scan and Cyclic Methods Applied to Reversible, Irreversible, and Kinetic Systems. Anal. Chem. 1964, 36 (4), 706-723.

(19) Folgueiras-Amador, A. A.; Philipps, K.; Guilbaud, S.; Poelakker, J.; Wirth, T. An Easy-to-Machine Electrochemical Flow Microreactor: Efficient Synthesis of Isoindolinone and Flow Functionalization. Angew. Chem., Int. Ed. 2017, 56 (48), 15446-15450.

(20) Folgueiras-Amador, A. A.; Wirth, T. Perspectives in Flow Electrochemistry. J. Flow Chem. 2017, 7 (3-4), 94-95.

(21) Bradley, D. C. Metal Alkoxides. Adv. Chem. Ser. 1959, 23, 210

(22) Msayib, K. J.; Watt, C. I. F. Ion Pairing and Reactivity of Alkali Metal Alkoxides. Chem. Soc. Rev. 1992, 21, 237-243.

(23) Wiebe, A.; Riehl, B.; Lips, S.; Franke, R.; Waldvogel, S. R. Unexpected High Robustness of Electrochemical Cross-Coupling for a Broad Range of Current Density. Sci. Adv. 2017, 3 (10), No. eaao3920. 
(24) Somerville, L.; Bareño, J.; Jennings, P.; McGordon, A.; Lyness, C.; Bloom, I. The Effect of Pre-Analysis Washing on the Surface Film of Graphite Electrodes. Electrochim. Acta 2016, 206, 70-76. 